\title{
Personal and Social Education: Curriculum Innovation and School Bureaucracies in Malta
}

\author{
Ronald G. Sultana \\ Faculty of Education \\ University of Malta
}

The rationale behind a personal and social education (PSE) initiative coordinated by the author in Malta' is critically reviewed. The social context for the emergence of PSE in a number of countries is compared and contrasted, linking this 'new' development with issues of legitimation on the one hand, and problems posed by bureaucratic school structures on the other. Some of the normative dilemmas with PSE are explored, notably its tendency to reduce 'education' to a technocratic focus on the development and learning of skills. It is suggested that there is a danger that PSE could become yet another compensatory divide which reinforces the social-control function of schools, but that this can be averted if there is a creative rapprochement between two disparate educational perspectives, namely humanistic education and critical theory/pedagogy. The convergence of the two approaches would ensure that both the personal and the political goals of a true education would be achieved.

This paper sets out to describe and analyse the introduction of personal and social education (henceforth referred to as PSE) in the formal national curriculum in Maltese schools ${ }^{2}$. The author was contracted by the Department of Education to act as consultant on the project, to provide a curriculum for PSE, and to co-ordinate in-service training programmes for future PSE teachers. In the first section of the paper, the emergence of PSE in a number of 'Western' countries - first as a distinct curricular area, then as a movement throughout the whole curriculum - is traced to its socioeconomic context. The second section of the paper explores why AngloSaxon experiments in PSE attracted Maltese educational authorities and policy-makers, and how curricular initiatives are adopted in post-colonial educational systems, even though the original intents for that initiative as expressed in the 'mother country' are subverted or significantly modified to address the particular concerns of the 'recipient country'. It is argued that while there are normative problems with the skills approach to education which PSE-type initiatives generally espouse, such programmes do provide a significant space through which counter-hegemonic and non-bureaucratic forms of educational experiences can be introduced. Finally. the PSE programme proposed for Maltese schools, together with the underlying rationale. is presented. 
The paper represents a formal attempt by the author to reflect critically on - and to theorise - his practice. Colleagues interested in comparative perspectives on PSE are invited to respond critically to what is argued below.

\section{The social contexts of PSE}

PSE has grown out of a very particular socio-economic context in a number of 'Western' capitalist economies. As has been argued elsewhere (Sultana, 1987a; 1989) with reference to the growth of PSE initiatives under such diverse names as 'lifeskills', 'transition education', and 'preparation for life curriculum' in the United Kingdom, Australia and New Zealand, PSE can perhaps be best understood utilising Habermas' (1976) concept of 'legitimation crisis'. Educational and occupational systems declare the need for motivation, but when the socio-cultural system fails to provide this motivation - in the case of the three countries mentioned above, through their failure to provide employment - a motivational crisis, the basis of a legitimation crisis, occurs. Schooling therefore begins to lose its legitimacy with students who fail to get the 'reward' they had striven for and been promised. A number of analyses suggest that both at the micro-level of school and classroom, as well as at the macro-level of policy-making, this crisis in employment has affected the form and function of educational systems. At the micro-level, for instance, Stronach and Weir (1983) have argued that high unemployment levels have led to the expansion of vocational preparation, and this has tended to move away from a strict focus on the market and towards an emphasis on 'personal development' as a consequence of the paradox that careers teachers had - and still have - to face: namely, preparing students for jobs that simply are not there. Similarly, Bates (1984) has traced the development of careers education and its transmutation from a focus on vocational guidance in the 1960s to 'lifeskills' and personal and social education in the depressed economy of the 1980s. A 'relevant curriculum' which set out to meet the personal and social needs of the young would compensate for the lack of motivation to invest in schooling.

At the macro-level, the legitimation crisis was met by a spate of educational reforms where a new definition of schooling - one which saw it tied more specifically to the interests of industry - was promulgated. In this context it is particularly useful to refer to Weiler's (1985) extension of the Habermasian theme to include what the former calls 'compensatory legitimation'. Weiler argues that modern states attempt to win credibility and acceptability from their citizens by a number of measures, including curriculum reform. Weiler (1985, p. 193) argues that the adoption of reform policies promotes legitimacy in two ways. First, it identifies an existing regime as forward-looking, flexible, and responsive to the changes of modern society, and thus enhances its credibility and legitimacy. Second 
[...] it is possible to look at reform policies, in education as well as in other policy areas, as strategies of "compensatory legitimation", that is, as ways to maximise the gains in legitimacy which the state, faced as it is with the erosion of its own legitimacy, may derive from the ways in which it goes about making and implementing policies of reform'.

Both the movement towards 'relevance' within the schools and the topdown pressure to make schools more responsive to the 'needs of industry' need to be seen in a dialectical perspective. In other words, reforms and changes in any social terrain embody within them contradictory moments, and need to be seen as sites of struggle where groups attempt to assert their specific interests (Apple, 1985). As Whitty (1985) among others has shown, the crisis in employment has led to the emergence of new forms of discourse, with some groups - the 'new' vocationalists - demanding greater standardisation of the curriculum and attempting to define and defend a core of 'central' subjects. The rise of the 'new' vocationalism has been documented in a number of countries (Sultana, 1987b; Shilling, 1988) and has by now become deeply entrenched in the concepts and language that are used with reference to education.

However, other forms of discourse have also emerged to counter the technocratisation of education. One of these is what can be referred to as 'rhetorical humanism', which argues that since the world of work is not only changing but vanishing (cf. Macarov, 1985), and since work may not even remain a key sociological category (cf. Offe, 1985), then education can disengage from its utilitarian functions and concentrate instead on personal and social education. A third form of discourse, drawing on critical theory perspectives as well as on neo-Marxist approaches to education, recognises the importance of the personal, but sets out to confront the dialectical links that exist between the personal and the political and between agency and structure. This approach argues that education should focus on empowering students to de-code the realities of the world they live in. It would include teaching critically about rather than for work (Shor, 1980; Simon, 1983), and provide not merely adaptive and coping skills, but also the understanding and the civic courage (Giroux, 1982) ${ }^{3}$ in order to engage the inequalities and injustices which prevail, so that emancipatory social relations can be developed.

Teachers often find themselves caught on the horns of a very uncomfortable dilemma, unable to resolve at a personal level contradictions which are created in the wider social order, and having to respond to one or more of the ultimately irreconcilable educational discourses outlined above. As Wexler et al. (1981) have argued in a North American context, teachers seem to be responding more readily to the technocratic language of vocationalism, to the extent that curriculum subjects are undergoing 'decomposition' - English becomes communication skills, social studies is transformed into social and life skills, and economics into a study of 
techniques rather than values - thereby reducing their potential for promoting critical understanding. This critique of the skills approach to a number of subjects has particular relevance to PSE, and will be picked up again in a later section of this paper. At this stage it is important to develop our awareness of the social contexts from which educational concepts and practices emerge, and to explore how PSE appeared in Malta in a very different socio-political and post-colonial context.

\section{The Maltese context}

For a number of reasons, Malta has not experienced the economic crisis as severely and as profoundly as the United Kingdom and other industrialised 'Western' countries have. Although young unemployed persons under 25 years of age constituted half of the total of those registering for work in the mid-1980s (Sultana, 1987a), welfare statism ${ }^{4}$ is firmly established, and a strong 'underground' economy - Delia (1987) has calculated that earnings from this sector could be as high as $10-20 \%$ of GNP - ensures that both the unemployed and the formally employed generally find ways and means to supplement their benefits on the one hand and their wages on the other. Schooling has not lost its legitimacy with students and their parents, but rather one notes a strong belief in credentialling as a sure way to attain security and social mobility, and hence heavy investment - in terms of both time and money - in formal educational pursuits ${ }^{5}$.

Following the de-streaming of primary state schools, the abandoning of formal examinations in favour of continuous assessment, and the comprehensivisation of state schools in 1972, the state educational sector did lose its legitimacy with parents owing to fears of lowering of standards. Teachers found themselves unprepared to adapt their pedagogy in order to cater for students of mixed abilities and interests (Darmanin, 1985). However, belief in the utilitarian benefits of education remained intact, for parents simply transferred their children to the private school system which had not gone comprehensive. As a result, around $30 \%$ of Maltese students are to be found in private schools (Zammit Mangion, 1988). An opinion poll carried out in 1984 (Times of Malta, 18 September 1984) showed clearly that even though state-school teachers were generally better qualified than those in private schools, $60 \%$ of Maltese parents still preferred to pay for their children's education, hoping that the lack of social-class mixing, the strictly academic curricula, and the special character of these largely Catholic schools would give them an extra advantage over those children who attended state schools (Tabone, 1987, p. 170).

Mainly owing to the pressure of the popularity enjoyed by private schools, and to its failed attempt at closing down the latter institutions (see Montebello and Borg, 1989), the Maltese Government decided to revert to a streamed and selective school system, and in 1981 created its version of élite academic schools - junior lyceums - which were to cater for the 
brightest and the best among those students whose parents could not afford to pay private-school fees. A left-wing government whose public image with reference to educational affairs and its comprehensivisation experiment - had been tarnished, could now claim some form of victory when confidence in the state school system was apparently restored and students 'lost' to the private schools were regained. The Labour Party's ideological conscience was assuaged when it claimed that a competitive and narrowly academic form of schooling which held its own against private schooling enabled working-class students - whose parents could not afford privateschool fees - to move into higher education.

The introduction of junior lyceums had a number of effects on the Maltese educational system, and a brief account of these will provide the essential background for understanding the recent appeal of personal and social education. Starting with the state primary education sector, parents' anxiety to have their children pass the national competitive exams in order to enter junior lyceums affected teachers, who more than ever before resorted to drilling, coaching for examinations, and focusing on the three examination subjects of mathematics, Maltese and English to the detriment of other subjects such as physical education, social studies, history. geography and arts and crafts. Falzon and Busuttil (1988) reported that $51.9 \%$ of state primary-level students - and $70.7 \%$ of all students who attended the stateschool system - went for private tuition after school hours and/or weekends. This clearly shows not only that education still enjoys legitimacy with Maltese parents, but also their eagerness to have their children enter into a higher-education-bound track.

This race for credentials became so intense that, with the change in government from Labour to National in 1987, the new education minister launched a campaign in favour of the 'education of the whole person'. Guidance counsellors gave talks to parents about the psychological and educational problems caused by a too strictly academic and competitive school system (Ministry of Education, 1988). The Minister also denounced private tutoring, and added religion and social studies as examination subjects required for entry into junior lyceums. While his intention was to have teachers, parents and students widen their hitherto exclusive focus on mathematics, English and Maltese, the result was that students began taking private lessons in five subjects instead of three (Falzon and Busuttil, 1988)!

Students who did not succeed in passing into the junior lyceum were channelled into area secondary schools and trade schools. In the latter schools especially, students - generally of a manual working-class origin (Sultana, 1991a) - found little that attracted them. A report on absenteeism in trade schools carried out in 1988 (Scicluna Calleya et al. , 1988) found that girls had an absence rate of $33 \%$ (or 50.5 days out of a total of 148 days) and boys one of $24 \%$ (or 35 days out of the same total). In $1989,46 \%$ of 15 -yearold students were missing from school when a survey questionnaire with all 
third-year students was carried out by the present author (Sultana, 1992a). Many of these were working in industrial establishments without the necessary school exemption which the law requires.

In the junior lyceums as in the primary schools, the same narrowly academic curriculum and the emphasis on examinations and competitive assessment prevailed. Students vied for the highest number of GCE passes, many sitting for the examinations from the fourth instead of the fifth year. In a study carried out in one of the junior lyceums which had opened by 1981 (Sultana, 1983), the present author - utilising a 'School Adaptation Check List' (Sultana, 1986) - discovered that a major difficulty which $83 \%$ of a random sample of 140 students were facing was the amount of homework given to them. $48 \%$ in fact mentioned this factor as one of their most pressing problems at school. $49 \%$ of students said that they were afraid of making mistakes at school, and another $49 \%$ that constant tests and examinations were a source of stress and anxiety: indeed, $14 \%$ felt that this latter was the major cause of unhappiness in their lives. $26 \%$ considered that school generated a feeling of failure, while $39 \%$ of the sample felt that school was all work and no play. The highly bureaucratic nature of the school meant that $60 \%$ of the sample felt that they could never speak on a personal level with their teachers, while $46 \%$ felt they could not ask questions in the classroom. $41 \%$ said that their teachers were much too strict, and $43 \%$ commented negatively about the style of discipline used by the teachers. $24 \%$ said they were actually afraid of some of the teachers. And yet the state - and parents - were promoting junior lyceums as the 'best' schools on the island!

\section{Importing curricula: PSE in Malta}

It was this scenario of stress and anxiety in the junior lyceum and the primary school sector on the one hand, and absenteeism in trade schools on the other, which facilitated the acceptance of personal and social education as a panacea for various ills. PSE promised to personalise the bureaucratic nature of the more competitive educational sectors, and to introduce topics more closely related to life in the trade-school sector. PSE would therefore humanise institutions and motivate students. The first experiments in the introduction of PSE curricula were carried out in church private schools, where it was introduced as a subject with a specific slot in the general timetable. Darmanin (1990) has correctly argued that private schools, free as they are from the centralised policy-making structure which hampers and constrains state schools, have been more ready to innovate and to respond to perceived student needs. Fenech (1992) notes, in his analysis of the history of curriculum innovation in Malta, that the state sector has tended to copy the innovations carried out in the private educational sector in its efforts to maintain credibility with the public. The models that were utilised in the church schools were generally those offered by Hopson and Scally (1980) 
and Button (1981). In the meantime, similar lifeskills projects were carried out in state schools on the initiative of counsellors during school breaks and occasionally on weekends. In the latter schools, therefore, PSE did not appear either as a formal subject on the curriculum, or as an attitude and approach to teaching and learning across the curriculum.

This started to change when in 1988 the Guidance and Counselling Services of the Department of Education invited a member of the Counselling and Career Development Unit at the University of Leeds to run a weeklong PSE course in Malta. While the counsellors who had been organising similar courses on the island on their own personal initiative felt that their efforts had been largely ignored - indeed, none of them were invited to contribute to the first formal PSE in-service course - the presence of expertise from abroad (always a key to understanding which ideas get accepted and which do not in a country with a post-colonial mentality) meant that PSE was highlighted at the policy-making level. Similarly influential was one of the directors of the Guidance and Counselling Services, whose mediating role with the Minister of Education was particularly crucial. In a small state such as Malta, personal political networks are important power resources (Zammit, 1984) and play an even more central role than Bates (1989) suggests in influencing curriculum policy-making and practice. All of this, it is argued, was instrumental in the formal inclusion of PSE in the National Minimum Curriculum in 1988. We find in Malta, therefore, a situation where PSE features formally and by law in the National Curriculum despite its general absence in schools, whereas in the UK it does not formally feature in the National Curriculum despite its prevalence in schools there.

\section{Problems with PSE}

There are a number of problems with the way PSE has been promoted in Malta. A key issue is the understanding of PSE as some form of skills training which helps students 'adapt to' and 'cope' with 'society'. Thus, the National Minimum Curriculum for primary schools stresses 'good behaviour and character formation', for instance, with emphasis being placed on the necessity of teaching students 'how to conduct themselves in society' (Council of Europe, 1989, p. 28). This is very close to the moral goals advocated for PSE by such authors as Pring (1984) and Straughan (1988), goals which J. White (1989) justifiably criticises on a number of grounds. As Simon (1988, p. 374) points out, what is often meant by 'character formation' is 'a particular narrowing of human capacities to fit particular forms'. The social control function of education as conceived in Malta generally - and with particular reference to PSE - became evident when the current Minister of Education addressed future PSE teachers. He expressed his concern that while in the past the family and the (Catholic) church could be counted upon for the reproduction of values and lifeskills from one generation to the next. 
it now fell more and more on schools to ensure the continuation of such a process.

Such a concern contrasts sharply with that expressed by Bowles and Gintis, for instance, who promote a very different understanding of personal and social skills. These authors (1988, p. 235) argue that one of the main goals of schools in a democratic society is the fostering of the personal development of each member of that society. However, 'this is not limited to the acquisition of knowledge and cognitive skills, but also affective and interpersonal skills which allow individuals to control their lives, and foster the self-esteem and sense of personal dignity which lead them to demand the resources to exercise such control' (emphasis added). In other words, the rationale behind - as well as the content and the social relations which form the context of the transmission of the content (i.e. pedagogy) of - PSE include a political orientation aimed not at 'adaptation' but at 'empowerment' and social transformation. Similar concerns regarding the social control/social change functions of school initiatives have influenced the approach to a field closely related to PSE, namely careers education and counselling (Watts and Herr, 1976).

The skills approach to teaching, which in an earlier section has been associated with the rise of the 'new' vocationalism in a number of countries, has been critiqued at a number of other levels. Skills, for instance, have been seen to reinforce an ideology which stresses industrial needs. Cathcart and Esland (1985, pp. 184-185) are worth quoting at some length in this regard:

'That creativity which drew its sustenance from the psychological theories of Piaget and existential philosophy was founded on an open-ended concept of cognition and an expanding consciousness in which the concrete and the abstract were seen in a continuing dialectical relationship. The ideal pedagogical mode, in the phrase of Freire, was "learning by discovery". By contrast, the innovation, initiative and enterprise called for in the current discourse are entirely instrumental. They are directed at practical or technical rather than intellectual development, at information rather than knowledge, at syncretism rather than understanding.'

The skills approach to teaching ironically and paradoxically deskills students because it alienates the latter from taking control of and understanding their own lives. As a consequence, students end up having little grasp of who they are in the world, or any real understanding of how and why they relate as they do to those institutions and individuals whose powers order and fashion their lives. Gorz (1976) has also pointed out that one cannot conceive of 'technique' outside the social relations in which it is embedded: thus the concept of skill is not just a technical question, but is also a question of power and interest. It follows that the emphasis on skills in modern education 
(Wexler et al., 1981; Blackmore, 1990), and particularly in the lifeskills and PSE curricula, mystifies the fact that such skills always refer to some socially defined version of what constitutes competence. Atkinson et al. (1982, p. 124) have also questioned whether an adequate curriculum of 'social and life skills' can in fact be formulated, given our lack of knowledge of their nature. They argue that 'teachers can be forgiven if they fall back on such "traditional" formal educational practices as drilling students in job application letters which could well have immediate benefit, but hardly matches up to the more grandiose claims of social and life skills'.

Another problem with PSE is that it is being adopted as an add-on programme, leaving much of the traditional curriculum untouched. In other words, while at the official level the state argues for forms of humanising education, it leaves untouched the structures which lead to the contradiction of its own discourse, so that the 'hidden curriculum' of schools actually works against the goals and intentions of PSE curricula. Galloway (1990, p. 31) identifies this problem as one of the more difficult challenges facing PSE, and argues for a state of affairs where 'the social climate in the classrooms throughout the school [...] facilitates the school's overall aims with respect to pupils' personal and social development'. Unless this happens, PSE initiatives can be considered to be little other than a "compensatory legitimation' measure, and they run the risk "of being regarded as a "bolt-on" attachment with no implications for the rest of the curriculum' (ibid, p. 31).

\section{The personal and the political in PSE}

PSE was conceived by the present author in such a way as to address the issues above, and to work within the dilemmas and contradictions which face anybody who strives for change within a particular existing system. This requires working - often uncomfortably - at two levels: "to face immediate problems doing "the best" for ... clients while appreciating all the time that these very actions may help to reproduce the structures within which the problems arise' (Willis, 1977, p. 186).

One way of making sense of these contradictory demands was to engage two broad schools of thought, namely humanistic education and critical theory. While hitherto these two approaches have, in Bell's and Schniedewind's (1987, p. 55) words, occupied different worlds of discourse, there recently have been efforts to combine the strengths of each perspective in order to mount a more effective challenge to the conservative agendas finding favour in a number of countries (Morrison, 1989). Bell and Schniedewind $(1987$, p. 56) have pointed out the contributions of the research, theory, and practice of humanistic education in providing 'frameworks and tools for making content meaningful to learners, for structuring learning experientially, for integrating intellectual and emotional development, and for creating supportive, co-operative, and democratic learning environments'. The same authors, however, point out that this approach is 
limited and ultimately self-defeating unless it strives to integrate the insights provided by critical theory. This would mean that the humanistic approach maintains its focus on the person but that it enlarges its vision to perceive people as embedded in social structures where power and interests to a large extent determine hitherto unproblematic key words and processes such as 'development', 'fulfilment', and 'self-actualisation'. In this regard, Bell and Schniedewind (1987, p. 58) write: 'By failing to consider institutional power and systematic oppression, humanistic educators do not follow their proposals to their logical conclusions. The kinds of learning they want for students can be functional in most students' lives only if the society changes drastically.'

Herein lies the strength of critical theory with its readiness to link education to economic, cultural and ideological processes while at the same time exploring the role of human agency. Critical theory perspectives refuse to be optimistic about personal and educational change without at the same time being optimistic about - and indeed emphasising the need for - societal reform and transformation (Fay, 1977). However, as has been pointed out in a number of contexts (Viegas Fernandes, 1988; Sultana, 1989; 1990), there has been little evidence of critical theorists moving from analysis and critique to the actual production of counter-hegemonic curricula and empowering pedagogic practices which can effectively challenge the reproduction of various forms of social inequality through schools. Although recently inroads have been made in establishing concrete links with classroom practice (Simon, 1983; Ashenden et al., 1984; Cohen, 1984; Jensen, 1986; Bates and Rowland, 1988; Sultana, 1990), it has been humanistic education perspectives - epitomised by developments first in 'lifeskills' and more lately in 'personal and social education' initiatives - that have taken the lead in developing fields of learning so that schools and classrooms do in fact become 'a lived experience of how the world can be different' (Lather, 1984, p. 55).

Bell and Schniedewind (1987, p. 62, p. 63) conclude that while humanistic education provides the tools for making education meaningful to learners, critical theory provides the analysis to make it critical: 'We propose that joining the two approaches can offer a coherent model for liberatory education that combines analysis and vision with strategies to achieve that vision [where] the critical theorists' agenda [provides] a historical and social framework for making sense of isolated facts and feelings.' Thus, as Carr and Kemmis (1986, pp. 33-34) point out, we enter into the realm of dialectical thinking: the search for, and acknowledgement of, contradictions in daily lives and practice. Schools are therefore seen as sites of both domination and liberation: 'school functions simultaneously as a means of empowering students around issues of social justice and as a means of sustaining, legitimizing and reproducing class interests directed at creating obedient, docile, and low-paid future workers' (McLaren, 1989, p. 167). 
Such insights are of strategic importance in any attempt to introduce a PSE approach which draws on both humanistic and critical theory discourse. Since teachers often operate within a 'culture of individualism' (Hargreaves, 1984), with a 'humanistic, child-centred and psychologistic conception of "teaching" and "learning" (Sachs and Smith, 1988, p. 427), their support for PSE - especially in the face of bureaucratic forms of management and the intrusion of 'new vocationalist' discourse and practice - is likely to be strong. It is, however, more difficult to draw teachers away from a cognitive style where the dominant images of child-centred progressivism of a liberal, individualistic kind encourage them to concentrate on individual student performance without regard to the social effect of schooling (Dale, 1977).

PSE as conceived in this paper has the advantage of engaging teachers' child-centred concern in the first instance, but then drawing them into a consideration of the social structuring of the same individuals that they are so willing to help. That this sequence can in fact take place - that is, that there can be a simultaneous engagement in humanistic and political discourse - has been recently suggested by Young (1990). There have been a number of analyses (Harris, 1982; Sachs and Smith, 1988; Sultana, 1989) which have stressed that the social class location of teachers as well as the cultural terrain in which they work often oblige them to avoid critical and political perspectives.

Young (1990, p. 42), however, has pointed out a number of factors particular to educators which make it possible - if not likely - for them to become involved in the kind of educational practice that is being proposed. Young argues that liberalism, rather more than new vocationalist discourse. lays itself open to politicisation, influenced as it is by classical philosophical traditions regarding the formation and development of the whole person: "traditions which enshrined notions of autonomy and of the responsibility of individuals for "taking their rights" - at least morally and intellectually rather than receiving them'. Young also points out that in the European educational tradition, 'the idea of each new generation transcending the old has also been present'. He argues that 'teachers possess a degree of institutionalised insulation from social norms and sanctions governing expression of opinion in other contexts of life', so that 'the school classroom has always been recognised as a territory where, to a degree, the exigencies of daily life are suspended'. Finally, Young suggests that 'schools keep alive an intuitive idea of critique, of the possibility of transcendence. which shows through in many unselfconscious "child-centred" educational experiments".

\section{Constructing a PSE curriculum}

It is with reference to the above critical perspectives on schooling and educational processes that the present author set about constructing a PSE curriculum and approach. Curriculum construction now represents a vast area of scholarship, and in this context, Apple's work (1982: 1985; 1986) - as 
well as that of Giroux $(1982 ; 1988)$ and Whitty $(1985)$ - has been particularly instrumental in identifying a number of principles and organising ideas guiding the formulation of the PSE curriculum outlined below. Especially helpful was Ashenden et al.'s (1984) manifesto for a democratic curriculum, for here the authors succeed in translating a complex debate, often engaging a large number of abstract concepts and processes, into a clear and schematic presentation which is reasonably accessible to educational practitioners.

Ashenden et al. (1984, p. 15) argue that a democratic curriculum should be common, where 'all students are able to progress consistently through all areas of the course'. With particular reference to PSE, it is imperative that it is not transformed into an alternative curriculum for the under-achieving, or for those who are 'unmotivated'. Bernstein (1971) and others have pointed out that often educational programmes which set out to be 'relevant' become a dumping ground for specific groups of students, often identifiable by their class background, hence creating 'curriculum ghettoes' for the working class (Connell, 1988, p. 64). In any case, as Sultana (1989, pp. 297298) has shown, the targeting of PSE-type programmes at the 'at-risk' is contested both by the latter group and by mainstream students. Ashenden $e t$ al. $(1984$, p. 15) also argue in favour of a curriculum that is inclusive, in the sense that is should include in its content 'the everyday experience of all its students and reflect the diverse character of the community'.

Connell $(1988$, p. 68$)$ goes even further to argue from a Rawlsian perspective on justice that curriculum construction should embark on a strategy of inverting hegemony by taking the standpoint of the least advantaged in a social system. Connell argues in favour of the 'organisation of content and method which builds on the experience of the disadvantaged [...] but attempts to generalise it to the whole system, rather than confining it to a section. It thus seeks a practical reconstruction of the system which will yield relative advantage to the groups currently disadvantaged. It attempts to turn a defensive, compensatory strategy into a pro-active, universalising strategy.'

A democratic curriculum consistent with the overt discourse of PSE should be premised on co-operation and success, rather than on competition and failure. It would therefore encourage forms of evaluation which involve self- and peer-assessment, joint-assessment, and discussion about individual progress measured against past achievement. Such a curriculum should be worthwhile, offering 'something of enduring relevance to the learners' (Ashenden et al., 1984, p. 15). It should also be coherent - with human knowledge growing and building on itself - and systematic, for only then can it be accessible to debate. In this sense, PSE should be seen as an interdisciplinary thematic investigation (Freire, 1972) whereby disciplines like science, social science and philosophy are harnessed in the quest for a deeper understanding of the issues involved.

A democratic PSE curriculum is therefore necessarily reflective, 'open to question and its application to one's framework of meaning has to be 
explored' (Ashenden et al., 1984, p. 15). It is also necessarily moral, fully aware of the myth of neutral knowledge, and convinced that learning is related to conceptions of right and wrong and of truth, compassion and justice. It is meant to give students the conceptual knowledge and the practical skills to negotiate and control their own lives as individuals within social contexts which include, among others, the family, the school, the work environment, and the political life of the region and country in which they live. PSE does not set out to teach students merely how to cope, but rather to critically approach individual and social 'realities', seeing the latter not as 'facts', but as historical constructions working in favour of particular interests.

Special attention needs to be given to the pedagogy of PSE, and indeed it has often been stated that PSE is as much a question of method as of content (J. White, 1989, pp. 16-17). Thus Ashenden et al. (1984, p. 15) argue that a democratic curriculum should be both practical and do-able. The former quality is necessary because 'a combination of doing and reflecting on the doing is more likely to make learning accessible to the largest range of students', while the latter quality sets out to ensure that the tasks set are structured in such a manner that participating students are able to carry them out. Such a pedagogy therefore safeguards the principles of inclusion and commonality discussed above.

We are here entering into the terrain of critical pedagogy, an approach which owes much to Freire (1972). He has been the most influential educator to merge humanistic and critical theory concerns in both his theory and his practice. The emphasis here is on a pedagogy which values dialogue, democratic participation, and the notion of culture as forum (Bruner, 1986, p. 65), with a focus on process rather than on pre-selected goals and ends. PSE, following Freire's 'problem-posing' model, should enhance a dialogic relationship between teacher-student and student-teacher in their cooperative search for knowledge and the good life. The quest is for school and classroom practices which are 'organized around forms of learning which serve to prepare students for responsible roles as transformative intellectuals, as community members, and as critically active citizens outside school' (Giroux and McLaren, 1986, p. 237).

Such a pedagogy encourages the asking of questions and the engagement with students' experiences. Although, as Bates and Rowland (1988) have argued, this experience is not in itself sufficient for the development of learning, it is an essential component of critical education both on epistemological and pedagogical grounds. Young (1988, p. 57) makes this point, showing that often teachers direct students' learning in such a way that teaching approximates more to indoctrination than to education, because goals (which in themselves might be unobjectionable regarding validity claims) are pursued 'in a manner which tends to result in students accepting these claims on grounds other than reasons which seem valid to them in their 
own frameworks of relevance'. Moreover, such a process is not only indoctrinating but also results in a shallow kind of knowledge, unconnected with students' deepest beliefs, which is soon forgotten after leaving school' (Young, 1988, p. 57).

\section{A PSE curriculum}

The PSE programme presented in table 1 is a 'curriculum' if the latter word is defined in terms of a guide to educational practice. The principles established in the preceding section should ensure that PSE teachers do not set out to channel the content towards students; neither should teachers feel the curriculum as some sort of imposition on them by more 'expert' educational theorists. As Apple (1985) has argued, a democratic curriculum, unlike pre-packaged programmes, de-skills neither teacher nor students: both are considered capable of producing knowledge rather than consuming it. This does not preclude teachers from using ready-made resources in a critical manner.

Five of the major categories, and many of the themes suggested for exploration within them, are common to a number of other PSE programmes that have been promoted by, among others, Hopson and Scally (1980) and Wilcox et al. (1984). Categories I, II, III, and V are largely selfexplanatory, drawing as they do on social-psychological concerns underpinning most initiatives of this nature. Category IV, i.e. 'Personal and Social Development at School', is novel and requires further elaboration. As Ashenden et al. (1984, p. 15, p. 18) argue, the school is one of the foremost institutions which shapes young people's subjectivities, and it is vital to open this social site for learning and discussion. Learning about the character of the social unit in which students and teachers work leads to an active understanding of the way other social units work. It also opens up spaces for the critical consideration of the values underlying school practices, and for the opportunity to channel the student voice towards those responsible for leadership so that more democratic and participative forms of social relations can be established.

While, as has been argued above, the curriculum is to be negotiated with students, and indeed the starting point of thematic investigation is the student, the teacher/facilitator has a particularly important leadership role to play. As Shor and Freire (1987, p. 103) point out, when the educator begins the dialogue, 'he or she knows a great deal first in terms of knowledge and second in terms of the horizons that she or he wants to get to'. It is important therefore that all the major categories and as many of the 'selves' as possible are explored. This will ensure that students investigate themes related not only to themselves as individuals, but also to other aspects of their social/ political lives as well. It must be emphasised that while the programme categorises a large number of themes under a variety of 'selves', this is merely a representational device: anybody who has facilitated experiential 
Table 1: A PSE curriculum

1. ASPECTS OF PERSONAL DEVELOPMENT

\section{Physical Self}

* How my body works

* Listening to my body

* Respecting my body

* Abusing my body

* Sexuality

* Body language

- Personal hygiene

* Diet

* My body through life stages

* Body maintenance

* Bio-rhythms

* Politics of the body

* Environmental sustenance

* Handicaps and limitations

\section{Thinking Self}

* Critical thinking

* Self-knowledge

* Identifying prejudices

- Developing thinking skills

* Decision-making skills

Emotional Self

* Personalities

* My emotions

* Expressing emotions

- Identifying values

- Stress prevention/management

* Self-acceptance

* Dealing with failure

* Self-discipline

- The integrated self

* Intuitive being

* The spiritual self

III. DEVELOPMENT WITHIN THE COMMUNITY

The Communal Self

- Myself as leader

- Myself as follower

* Myself as consumer

- Consuming ideas/attitudes

- Helping agencies

- Sex/race ster eotyping

- Caring for environment

- Social classes

* Public speaking

- The oppressed

* Aspects of community culture

\section{DEVELOPMENT WTTHIN}

\section{RELATIONSHIPS}

\section{Retating Self}

* Making friends

* How to listen

- How to communicate

* Assertiveness training

- Maintaining relationships

* Ending a relationship

- Relating with adults

- Relating with peers

- Confrontation skills

- Transactional analysis

* Giving/receiving feedback

- Skilled helping

* Sensitivity training

- Dynamics of groups/family

* Revealing self to others

\section{Gendered Self}

- Myself as female

- Myself as male

- Relating with opposite sex

* Sexual orientation

* Sexuality and communication

* Gender and roles today

- Males, anger and violence
IV. PERSONAL AND SOCIAL. DEVELOPMENT AT SCHOOL

The Integrating Self: Myself and the System

- Transition primary/secondary

- School structures

- Systems analysis

- Discovering values of school

- Promoting change in school

* Student representation

* Confronting/negotiating

* Management styles

* Bureaucracies 


\begin{tabular}{|c|c|}
\hline $\begin{array}{l}\text { Political Self } \\
\text { " What is politics? } \\
\text { " Participation } \\
\text { * Alternative social forms } \\
\text { "Alternative economic forms } \\
\text { " Who wields power? How? } \\
\text { " Conflicting interests } \\
\text { * People power } \\
\text { * Change-agent skills }\end{array}$ & $\begin{array}{l}\text { Myself as Learner } \\
\text { * Learning how to learn } \\
\text { * Learning from experience } \\
\text { * Study skills } \\
\text { * Note-taking } \\
\text { * Research skills } \\
\text { * Authoring knowledge } \\
\text { * Problem-solving } \\
\text { * Lateral thinking } \\
\text { * Knowing community resources } \\
\text { * Tackling exams } \\
\text { * Concentration skills } \\
\text { * Lifelong education } \\
\end{array}$ \\
\hline 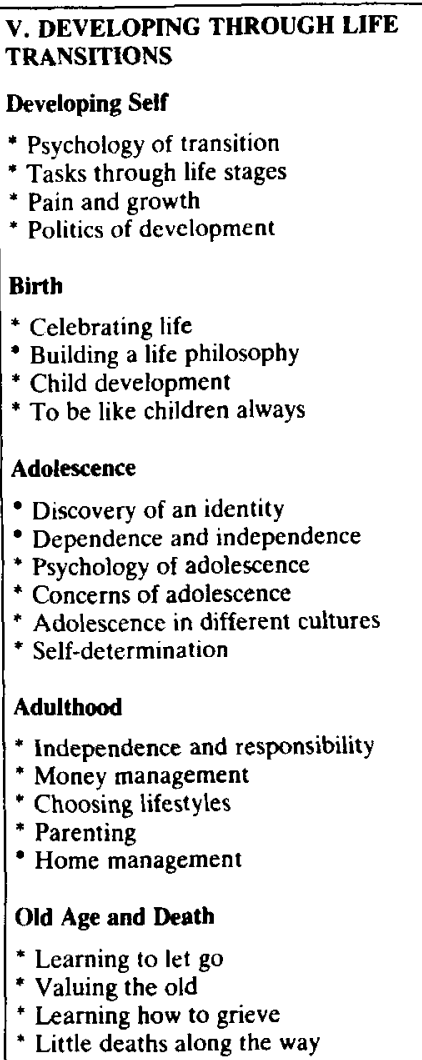 & $\begin{array}{l}\text { VI. DEVELOPING THROUGH WORK AND } \\
\text { NON-WORK } \\
\text { Working Self: Pre-Employment Aspects } \\
\text { * Occupational awareness } \\
\text { - Occupational decision-making } \\
\text { * Gender and occupational choice } \\
\text { * Class and occupational choice } \\
\text { * Job-getting } \\
\text { * Interview skills } \\
\text { * Assessing jobs } \\
\text { - Primary and secondary labour markets } \\
\text { Aspects of Employment } \\
\text { * Different modes of production } \\
\text { * How industry works } \\
\text { - Worker participation } \\
\text { - Self-employment } \\
\text { - Male and female workers } \\
\text { - Trade unions } \\
\text { * Pndustrial relations } \\
\text { * Ecological issues } \\
\text { - Part-time work } \\
\text { - Exploitative relations } \\
\text { * Alienation } \\
\text { * Sexual harassment } \\
\text { Playful Self } \\
\text { * Bifurcation work/leisure } \\
\text { * Creative use of leisure } \\
\text { * Understanding unemployment } \\
\text { * Sources of help } \\
\text { * Leisure and health }\end{array}$ \\
\hline
\end{tabular}

learning sessions will be aware of the holistic nature of such encounters. Fragmentation of knowledge is more typical of the traditional approach to the curriculum and is anathema to the practice that is being promoted here. 
Indeed, the problem-solving/experiential inquiry method is an ideal basis for a degree of integration of knowledge.

An important point needs also to be made about the specific themes which appear in the different categories. There is of course no guarantee that the treatment of these themes will lead to the rapprochement of the humanistic and critical approaches described earlier. It would be useful in this context to consider the distinction that Giroux (1988) makes between micro and macro objectives, with the former being concerned with what he calls 'productive knowledge', and the latter with 'directive knowledge'. Productive knowledge - what Habermas (1972) refers to as 'technocratic rationality' - is technical, skill-oriented, and pre-determined. It focuses on facts and certainties, and its major concerns are organisation, classification, mastcry and manipulation of data. PSE should, following the perspective adopted in this article, be more concerned with 'directive knowledge' - what Habermas refers to as 'emancipatory rationality': that is, with a dialectical mode of enquiry which recognises the social function of particular forms of knowledge. The concern here is with 'macro objectives' which centre on the relationship between means and ends, between specific events and skills and their wider social and political implications.

A consideration of 'Myself as Male', for instance, would draw on the experiences of students, with inputs from various disciplines helping to contribute to a fuller understanding of the issues involved. Biology, sociology, cultural studies, film, ethnographic fieldnotes collected by students themselves, observation of family, work and recreational life, etc. could all help in this thematic investigation. A special focus could be placed on how masculinity is expressed in the students' particular country/region, and the relativity of this can be explored by comparing such an expression with that of other regions/countries. Furthermore, a moral/normative stance could be introduced in the consideration of how certain forms of expression of masculinity are experienced as forms of oppression by other groups, notably women. Aspects of women's studies can be profitably introduced. Counselling strategies such as modelling could bc used to explore alternative and constructive ways of expressing anger and aggression. The politics of gender relations could be discussed, and an analysis of images of males on the media would certainly be relevant. In Malta, for instance, one would need to look closely at how institutions such as the Catholic church encourage patriarchal hierarchies and systems of power.

It should be quite clear by now that 'thematic investigation' needs a highly prepared facilitator, one who is not only aware of the cognitive challenges such a PSE programme represents, but is also, in Rogers' (1961) terms, 'a person in process', open to learning and to challenges which inevitably arise in the open-ended educational encounter with students. Needless to say, this represents one of the most daunting problems of implementing PSE as it is understood in this context - at least in Malta. 
Finally, the PSE programme under discussion has a vertical dimension to it in the sense that some topics can be more profitably addressed at a specific age, and also that one can return to the same topic at different stages throughout the students' career at school. While the author is critical of a stage-approach to development as advocated by the likes of Piaget or Erikson, and agrees with Gillham (1978) and Henriques et al. (1984) who have argued that in many ways age is socially constructed, it is nevertheless useful to keep broad developmental concerns in mind when approaching the themes highlighted.

\section{Conclusion}

The arguments and principles organised in this article with reference to PSE are, I am convinced, applicable to other areas of the school curriculum. Indeed, as J.White (1989, p. 17) has argued, it is difficult to see PSE as a mere adjunct to the curriculum rather than as an inextricable part of it: 'For the aims suggested could well be seen as the aims of school learning as a whole - or, indeed, of upbringing itself.' White also poses the problem that 'if all aspects of the school's life are thus to be brought under the aegis of PSE, is there then a case for the eventual abolition of PSE classes as part of the timetable?' This question is a logical sequitur of the first statement, and falls under those kinds of arguments which are made in favour of PSE across the curriculum. Indeed, there is a sense in which PSE as a subject is a contradiction in terms: to mention just one example, its discourse promotes interdisciplinarity of knowledge but its practice is isolated from other subjects. However, there must be some kind of pragmatic way through the conundrum that critical theorists consistently face in their attempt to engage in the world as it is, in order to bring about a state of affairs as it could and should be. As Galloway (1990, p. 31) puts it: 'Theoretically, the idea that everything that happens in school, both in the official curriculum and in the hidden curriculum, contributes beneficially to pupils' personal and social development is an attractive one. The question is simply how we reach that happy state of affairs.'

One way out of this is to see PSE as an instance of what can be referred to as the 'politics of difference', whereby the establishment of alternative practice within a school site in one area of the curriculum could have a salutary effect on the whole organisation. Successful PSE experiments along the norms established in this paper could, and indeed should, incite teachers and administrators, as well as students and parents, to reflect critically on the meaning of education. Thus, it is hoped that PSE as it has been conceived in Malta will drive a humanistic and critical wedge into the bureaucratic forms of schooling that currently prevail.

Knowledge of the politics of the curriculum, however, makes the author sceptical about the effectiveness of the strategy of the politics of difference unless this is buttressed by a grass-roots movement among teachers and 
parents. Such a movement is necessary in order to generate new and democratic visions about education, and new forms of discourse which would compete with what Weber correctly referred to as the increasing rationalisation, technocratisation and bureaucratisation of life forms ${ }^{6}$. It would therefore only be appropriate to point out that the author, together with faculty colleagues, students and teachers, has recently set up a Movement for Humanistic Education which embraces the educational approach proposed above, and which utilises a number of strategies to help such principles gain currency both at the grass roots in schools and communities as well as among educational policy-makers. Among these strategies are the development of action-research groups in schools, the utilisation of television, radio and newspapers for the promulgation of educational ideas, and the organisation of regular dialogic meetings with teachers and parents in village communities - where, through drama, songs and other media, issues pertinent to PSE (from a humanistic and critical theory perspective) are discussed (Sultana, 1992b).

\section{Notes}

1 Malta is made up of a group of small islands, two of which are inhabited. The larger island, Malta, has a population of around 325,000 , while Gozo's population is around 25,000 . The archipelago of islands covers a surface area of about 316 square kilometres. It occupies a strategic position in the Mediterranean. Iying 93 kilometres to the south of Sicily and 290 kilometres to the north of the African coast. Its position in the middle of the Mediterranean and its natural harbours have invited a number of colonial powers - the Carthaginians, the Romans, the Byzantines, the Arabs, the Normans, the various royal houses of Spain. the French, and finally the British - to take possession of the islands. Malta obtained its political independence from Britain in 1964, and was declared a republic in 1973.

2 Malta's state schools are closely modelled on the British system. Kindergartens are available free of charge for all students from the age of three upwards. Primary schooling extends from the age of five. which marks the beginning of compulsory attendance. to the age of eleven. Students then sit national examinations and proceed to junior lyceums, area secondary schools, or opportunity schools, depending on their performance and choice. After two years of secondary schooling. students can opt to transfer to trade schools, a system which leads either to employment or to technical institutes. Secondary-school students can opt to proceed through sixth form to university, or to one of several specialised vocational schools. The schoolleaving age was raised to 16 in 1974, and most students aim to get English credentials, including GCE Oand A-levels, as well as City and Guilds certificates. A number of private schools provide parallel kindergarten, primary, secondary and sixth-form services. Most of these schools belong to the Catholic church, but since 1987 there has been a tendency to set up secular private schools.

3 P. White (1989), following a liberal rather than critical theory perspective, makes the same point about the relationship between PSE and the virtue of courage. She argues for a kind of education which prepares young people for life as democratic citizens by fostering commitment to the values of democracy and encouraging them to reflect on the priority this has in the light of their other concerns, helping them to acquire relevant knowledge through a broad curriculum and encouraging them to develop the skills and attitudes of democrats dynamically through the experience of life in a democratic educational institution' (ibid, 1989, p. 97).

4 These include: the introduction of the national minimum wage and the compulsory payment of a yearly bonus to all workers as from 1975; the granting of parity of women's wages with those of men. in 1976; the compulsory grant of a cost-of-living increase to workers in the private sector and the payment of adult wage rates at the age of 18 as of 1977 ; the introduction of children's allowance in 1974; the regular increase of oldage pensions, national insurance benefits and social assistance payments; the introduction of a national health scheme by which services are freely available; and the provision of a large number of dwellings to solve the housing problem (Tabone, 1987. p. 134.).

5. That this investment favours particular groups of students, and that therefore meritocracy in Malta as elsewhere is largely a myth, has been documented in detail by the present author (Sultana, 1991a).

6.The relationship between social movements and the political activities of teachers within schools is explored in Sultana (1991b). 


\section{References}

Apple, M. (ed.): Cultural and Economic Reproduction in Education. Boston: Routledge \& Kegan Paul, 1982.

Apple, M.: Education and Power. Boston: Routledge \& Kegan Paul, 1985.

Apple, M.: Teachers and Texts. New York: Routledge \& Kegan Paul, 1986.

Ashenden, D., Blackburn, J., Hannan, B., and White, D.: 'Manifesto for a Democratic Curriculum' . The Australian Teacher, No. 7, 1984.

Atkinson, P., Rees, T.L., Shone, D., and Williamson, H.: 'Social and Life Skills: the Latest Case of Compensatory Education'. In Rees, T.L. and Atkinson, P. (eds.): Youth Unemployment and State Intervention. London: Routledge \& Kegan Paul, 1982.

Bates, I.: 'From Vocational Guidance to Lifeskills: Historical Perspectives on Careers Education'. In Bates, I., et al. Schooling for the Dole: the New Vocationalism. London: Macmillan, 1984.

Bates, I.: 'Versions of Vocationalism: an Analysis of Some Social and Political Influences on Curriculum Policy and Practice'. British Journal of Sociology of Education, Volume 10 No.2, 1989.

Bates, I., and Rowland, S.: 'Is Student-Centred Pedagogy "Progressive" Educational Practice?' Journal of Further and Higher Education, Volume 12 No. 3, 1988.

Bell, L., and Schniedewind, N.: 'Reflective Minds/Intentional Hearts: Joining Humanistic Education and Critical Theory for Liberating Education. Journal of Education (Boston), Volume 169 No.2, 1987.

Bernstein, B.: 'On the Classification and Framing of School Knowledge'. In Young, M.F.D. (ed.): Knowledge and Control. London: Collier-Macmillan, 1971.

Blackmore, J.: 'The Text and Context of Vocationalism'. Journal of Curriculum Studies, Volume 22 No. 2, 1990.

Bowles, S., and Gintis, H.: 'A Reply to our Critics'. In Cole, M. (ed.): Bowles and Gintis Revisited. Lewes: Falmer, 1988.

Bruner, J.: Actual Minds, Possible Worlds. Cambridge, Massachusetts: Harvard University Press, 1986.

Button, L.: Group Tutoring for the Form Teacher: a Developmental Model. London: Hodder and Stoughton, 1981.

Carr, W., and Kemmis, S.: Becoming Critical. Lewes: Falmer, 1986.

Cathcart, H., and Esland, G.: 'The Compliant-Creative Worker: the Ideological Reconstruction of the School-Leaver'. In Barton, L., and Walker, S. (eds.): Education and Social Change. London: Croom Helm, 1985.

Cohen, P.: 'Against the New Vocationalism'. In Bates, I., et al.: Schooling for the Dole: the New Vocationalism. London: Macmillan, 1984.

Connell, R.W.: 'Curriculum Politics. Hegemony and Strategies of Social Change'. Curriculum and Teaching, Volume 3 Nos. $1-2,1988$.

Council of Europe: Newsletter 2/89, 1989.

Dale, R.: 'Implications of the Rediscovery of the Hidden Curriculum for the Sociology of Teaching' In Gleeson, D. (ed.): Identity and Structure: Issues in the Sociology of Education. Driffield: Nafferton, 1977.

Darmanin, M.: 'Malta's Teachers and Social Change'. In Lawn, M. (ed.): The Politics of Teacher Unionism: International Perspectives. Sevenoaks, Kent: Croom Helm, 1985.

Darmanin, M.: 'Maltese Primary School Teachers' Experience of Centralised Policies'. British Journal of Sociology of Education, Volume 11 No. 3. 1990.

Delia, E.P.: The Task Ahead - Dimension, Ideologies and Policies: Study of the State of the Maltese Economy. Malta: Confederation of Private Enterprise, 1987.

Falzon, P.A., and Busuttil, J.: Private Tuition in Malta. BEduc dissertation, University of Malta, 1988.

Fay, B.: 'How People Change Themselves: the Relationship between Critical Theory and its Audience'. In Ball, T. (ed.): Political Theory and Praxis: New Perspectives. Minneapolis: University of Minnesota Press, 1977.

Fenech, J.: Primary Schools in Malta: Historical and Ethnographic Study. PhD dissertation, University of London Institute of Education, 1992 (submitted).

Freire, P.: Pedagogy of the Oppressed. Harmondsworth: Penguin, 1972.

Galloway, D.: Pupil Welfare and Counselling: an Approach to Personal and Social Education across the Curriculum. London: Longman, 1990.

Gillham, B.: Reconstructing Educational Psychology. London: Croom Helm, 1978.

Giroux, H.: Theory and Resistance in Education. South Hadley: Bergin \& Garvey, 1982. 
Giroux, H.: Teachers as Intellectuals: Toward a Critical Pedagogy of Learning. South Hadley: Bergin \& Garvey, 1988.

Giroux, H., and Mclaren, P.: Teacher Education and the Politics of Engagement: the Case for Democratic Schooling'. Harvard Educational Review, Volume 56 No. 3, 1986.

Gorz, A.: 'Technology, Technicians and Class Struggle'. In Gorz, A. (ed.): The Division of Labour: the Process of Class Siruggle in Modern Capitalism. Atlantic Highlands. NJ: Humanities Press. 1976.

Habermas, J.: Knowledge and Human Interests. London: Heinemann, 1972.

Habermas, J.: Legitimation Crisis. London: Heinemann, 1976.

Hargreaves. A.: 'Experience Counts. Theory Doesn't: How Teachers Talk about their Work'. Sociology of Education, Volume 57, 1984.

Harris, K.: Teachers and Classes. Boston: Routledge \& Kegan Paul. 1982.

Henriques, J., Hollway, W., Walkerdine, V., Urwin, C., and Venn, C. (eds.): Changing the Subject: Psychology, Social Regulation and Subjectivity. London: Methuen, 1984.

Hopson, B., and Scally, M.: Lifeskills Teaching Programmes. Leeds: Leeds University Printing Service, 1980.

Jensen: K.: 'Work, Education and Democratisation'. In Walker. S. and Barton. L. (eds.) : Youth, Unemployment and Schooling. Milton Keynes: Open University Press, 1986.

Lather, P.: 'Critical Theory. Curricular Transformation and Feminist Mainstreaming'. Journal of Education (Boston), Volume 166 No. 1. 1984.

Macarov, D.: 'Planning for a Probability: the Almost-Workless World'. International Labour Revies: Volume 124 No. 6, 1985.

McLaren, P.: Life in Schools. New York: Longman, 1989

Ministry of Education: Education Report. Beltissebh: Maita, 1988.

Montebello, M., and Borg, R.: The Case of Church Schools in Malta. BEduc dissertation, University of Malta, 1989

Morrison. K.: 'Bringing Progressivism into a Critical Theory of Education'. British Journal of Sociology of Education, Volume 10 No. 1, 1989

Offe, C.: Disorganised Capitalism. Cambridge: Polity Press, 1985.

Pring, R.: Personal and Social Education in the Curriculum. London: Hodder \& Stoughton, 1984.

Rogers, C.: On Becoming a Person. Boston: Houghton-Mifflin. 1961.

Sachs, J. and Smith, R.: 'Constructing Teacher Culture'. British Journal of Sociology' of Education. Volume 21 No. 1, 1988

Scicluna Calleya, S., Sultana, R. . and Zammit, R.: Absenteeism in Trade Schools. Malta: Guidance and Counselling Services, Department of Education. 1988 (mimeo).

Shilling, C.: Schooling in Capitalist Britain. Lewes: Falmer, 1988.

Shor, I.: Critical Teaching and Everyday Life. Montreal: Black Rose, 1980.

Shor, I.. and Freire, P.: A Pedagogy for Liberation: Dialogues on Transforming Education. South Hadley: Bergin \& Garvey, 1987

Simon, R.: 'But Who Will Let You Do It?: Counter-Hegemonic Possibilities for Work Education' Journal of Education (Boston), Volume 165 No. 3, 1983.

Simon, R.: 'For a Pedagogy of Possibility'. Critical Pedagogy Nerwork, Volume 1 No. 1. 1988.

Straughan, R.: Can We Teach Children to be Good?: Basic Issues in Moral, Personal and Social Education. Milton Keynes: Open University Press, 1988.

Stronach, I., and Weir. A.D.: Once Upon a Timetable. Glasgow: Jordanhill College of Education. 1983.

Sultana, R.G.: 'The Adolescent and the School: a Survey'. Reading: University of Reading, 1983 (mimeo).

Sultana, R.G.: 'Counsellors as Transformative Agents: a Tool and a Methodology'. New Zealand Counselling and Guidance Association Journal, Volume 8 No. 1, 1986.

Sultana. R.G.: 'Educational Responses to the Unemployment Crisis'. Education (Malta), Volume 3 No. $1,1987(\mathrm{a})$.

Sultana. R.G.: Schooling for Work in New Zealand: a Qualitative Analysis of Three High Schools. Unpublished DPhil dissertation, University of Waikato, 1987(b).

Sultana, R.G.: 'Transition Education, Student Contestation and the Production of Meaning'. British Journal of Sociology of Education, Volume 10 No. 3, 1989.

Sultana, R.G.: 'Towards a Critical Teaching Practice: Notes for the Teacher Educator'. Journal of Further and Higher Education. Volume 14 No. 1, 1990.

Sultana, R.G.: 'Social Class and Educational Achievement in Malta'. In Sultana, R.G. (ed.): Themes in Education: a Maltese Reader. Msida: Mireva, 1991(a) (in press). 
Sultana R.G.: 'Social Movements and the Transformation of Teachers' Work: Case Studies from New Zealand'. Research Papers in Education, Volume 6 No. 2. 1991(b).

Sultana, R.G.: 'Child Labour in Malta'. British Journal of Education and Work, 1992(a) (submitted).

Sultana, R.G.: 'Teacher Power and the Struggle for Democracy: an Educational Movement in Malta'. International Studies in Sociology of Education, Volume 2, 1992(b) (in press).

Tabone, C.: The Secularization of the Family in Changing Malta. Malta: Domenican Publications. 1987.

Viegas Fernandes, J. 'From the Theories of Social and Cultural Reproduction to the Theory of Resistance'. British Journal of Sociology of Education, Volume 9, 1988.

Watts, A.G., and Herr, E.L. 'Careers Education in Britain and the USA: Contrasts and Common Problems'. British Journal of Guidance and Counselling, Volume 4 No. 2, 1976.

Weiler, H.: 'Politics of Educational Reform'. In Merritt, R.L., and Merritt, A.J. (eds.): Innovation in the Public Sector. Beverly Hills: Sage, 1985.

Wexler, P., Whitson, T., and Moskowitz, E.: 'Deschooling by Default'. Interchange, Volume 12 No. $2 / 3,1981$.

White, J.: 'The Aims of Personal and Social Education'. In White, P. (ed.) Personal and Social Education: Philosophical Perspectives. London: Kogan Page, 1989.

White, P.: 'Educating Courageous Citizens'. In White, P. (ed.): Personal and Social Education: Philosophical Perspectives. London: Kogan Page, 1989.

Whitty, G.: Sociology and School Knowledge. London: Methuen 1985.

Wilcox, B., Dunn, J.. Lavercombe, S., and Burn, L.: The Preparation for Life Curriculum. London: Croom Helm, 1984.

Willis, P.: Learning to Labour. Farnborough: Saxon House, 1977.

Young, R.E.: 'Critical Teaching and Learning'. Educational Theory, Volume 38 No. 1, 1988.

Young, R.E.: A Critical Theory of Education: Habermas and our Children's Futures. New York: Teachers' College Press, 1990.

Zammit, E.L.: A Colonial Inheritance. Msida: Malta University Press, 1984.

Zammit Mangion, J.: 'An Analysis of the Expansion and Growth of Education in Malta since 1946'. In Farrugia, C. (ed.): Education in Malta: a Look to the Future. Paris: UNESCO, 1988.

Received 31 January 1991; final revisions received 10 May 1991.

Correspondence should be addressed to: Dr Ronald G. Sultana, Department of Educational Studies, Faculty of Education, University of Malta, Msida, Malta. 